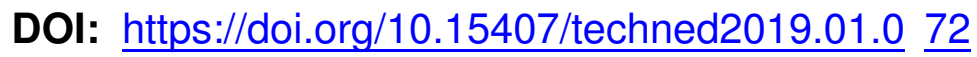

\title{
MODELING AND OPTIMIZATION OF NEW GLASS MELTING FURNACE WITH "INNER" INDUCTOR
}

Journal

Publisher

ISSN

Issue

Pages
Tekhnichna elektrodynamika

Institute of Electrodynamics National Academy of Science of Ukraine 1607-7970 (print), 2218-1903 (online)

No 1, 2019 (January/February)

$72-78$

\section{Authors}

\section{I.V. Volkov*, I.M. Kucheriava}

Institute of Electrodynamics of National Academy of Sciences of Ukraine,

pr. Peremohy, 56, Kyiv, 03057, Ukraine,

e-mail: ig.volkov@ukr.net

* ORCID ID : http://orcid.org/0000-0002-0696-0382

\section{Abstract}

The mathematical modeling of electromagnetic and thermal processes in the induction glass melting furnace of new design is carried out. The furnace has a closed magnetic core that envelops both an inductor and a crucible in the form of a hollow circular chute. The possibility and expediency of the furnace operation with industrial frequency $(50 \mathrm{~Hz})$ power-line supply are grounded. The basic characteristics of the furnace are compared with the corresponding 
characteristics of traditional induction furnaces. As shown, the specific electric energy consumption and power consumption from line are substantially less for the proposed furnace. The propositions for furnace parameters providing the optimized energy characteristics are given. References 9, figures 6, table 1.

Key words: glass melting furnace, induction heating, magnetic core, energy characteristics, current control, computer modeling, optimization.

Received: 30.08 .2018

Accepted: 03.09 .2018

Published: 10.01 .2019

\section{References}

1. Glasstronics. URL: http://www.glasstronics.co.uk/news.html

2. Yakovchuk P.E., Soltusik P.A., Pochapska I.Ya. The features of application of electroheating in glass production. Visnyk Natsionalnoho universytetu Lvivska polytechnika, Elektroenerhetychni ta elektromekhanichni systemy . 2009. No 654. Pp. 277-280. (Ukr)

3. Loboda A.S., Dub V.C., Yakubov Sh.A., Litvak V.A. Induction crucible furnace. Patent SU 1091005 A, 1984. (Rus)

4. Diatlov V.A., Cheltygdashev M.P., Shiriaev A.V. Induction crucible furnace-thermos. Patent RU 2213311, 2003. (Rus)

5. Hubert M. Basics of industrial glass melting furnaces. IMI-NFG Course on Processing in Glass, 2015. 75 p. URL: https://www.lehigh.edu/imi/teched/GlassProcess/Lectures/Lecture03 Hubert industglassmeltfurnaces.pdf

6. Tovazhnianskii L.L., Koshelnik V.M., Solovei V.V., Koshelnik A.V. Integrated energy-efficient thermal technologies in glass production. Kharkiv: NTU KhPI, 2008. 628 p. (Rus) 
7. Volkov I.V., Podoltsev O.D., Kucheriava I.M. Electromagnetic, thermal and hydrodynamic processes at induction heating of output channel of glass melting furnace. Pratsi Instytutu Elektrodynamiky NAN Ukrainy

. 2018. No 51. Pp. 113-120. (Rus)

8. Podoltsev O.D., Kucheriava I.M. Multiphysics modeling of electrotechnical devices. Tekhnich na Elektrodynamika.

2015. No 2. Pp. 3-15. (Rus)

9. Comsol multiphysics modeling and simulation software. URL: http://www.comsol.com/

$\underline{\text { PDF }}$ 